Jurnal Teknologi Pendidikan, Vol. 14, No. 1, April 2021, e-ISSN: 2407-7437

\title{
PENGEMBANGAN MEDIA INTERAKTIF HACE (HYDROCARBON) DALAM MEREDUKSI MISKONSEPSI PESERTA DIDIK DENGAN STRATEGI CONCEPTUAL CHANGE TEXT PADA MATERI HIDROKARBON
}

\author{
Elvin Yudha Pratama ${ }^{1}$,Sukarmin ${ }^{2}$ \\ ${ }^{1,2}$ Universitas Negeri Surabaya \\ 1'yudhax7@gmail.com, ${ }^{2}$ sukarmin@unesa.ac.id
}

\begin{abstract}
Abstrak: Tujuan dilakukannya penelitian ini adalah untuk mendeteksi dan mereduksi miskonsepsi peserta didik pada materi hidrokarbon dengan menggunakan media interaktif. Penggunaan media interaktif dimakusdkan untuk menambah minat peserta didik dalam pembelejaran. Subjek penelitian ini adalah peserta didik kelas XI SMA sederajat yang telah memperoleh materi hidrokarbon. Penelitian pengembangan yang dilakukan pada penelitian ini menggunakan three-tier diagnostic test yang dikombinasikan dengan conceptual change text. Pada three-tier diagnostic test disajikan dalam tiga tahap, yaitu soal, alasan menjawab soal dan keyakinan menjawab soal. Sedangkan pada conceptual change text dilakukan dalam empat tahap, yaitu menunjukkan konsepsi peserta didik, konflik kognitif, ekuilibrasi dan rekontruksi. Hasil dari penelitian ini berupa pergeseran miskonsepsi peserta didik yang telah melalui tahapan-tahapan mereduksi miskonsepsi. Media dikatakan efektif dan mampu mereduksi miskonsepsi peserta didik dibidang hidrokarbon apabila terjadi pergeseran miskonsepsi dengan presentase $\geq 60 \%$.
\end{abstract}

Kata Kunci: Peserta didik, miskonsepsi, penelitian

\begin{abstract}
The purpose of this research is to detect and reduce students' misconceptions on hydrocarbon material using interactive media. The use of interactive media is intended to increase the interest of students in learning. The subjects of this study were students of class XI SMA and equivalent who had obtained hydrocarbon material. The development research conducted in this study used a three-tier diagnostic test combined with a conceptual change text. The three-tier diagnostic test is presented in three stages, namely questions, reasons for answering questions and confidence in answering questions. While the conceptual change text is carried out in four stages, namely showing the students' conception, cognitive conflict, equilibration and reconstruction. The results of this study are in the form of a shift in the misconceptions of students who have gone through the stages of reducing misconceptions. Media is said to be effective and able to reduce student misconceptions in the field of hydrocarbons if there is a shift in misconceptions with a percentage of $\geq 60 \%$.
\end{abstract}

Keywords: Students, misconceptions, research

\section{PENDAHULUAN}

Peran guru dalam membimbing perserta didik saat proses pembangunan dalam berfikir sangatlah penting. Perbedaan pengalaman yang di alami peserta didik dan guru akan dapat memberikan efek yang cukup signifikan. Saat berfikir, peserta didik sering kali membuat kesalahan karena baru mengenal fakta-fakta di dalam bidang sains, oleh karena hal itu guru dapat membimbing peserta didik dengan pengalaman yang sudah mereka dapatkan untuk mengiringi proses belajar peserta didik serta dapat memperbaiki kesalahan berfikir yang dialami oleh peserta didik. Kesalahpahaman berfikir tersebut biasa dinamakan dengan miskonsepsi (Yuliati, 2017).

Miskonsepsi adalah kesalahpahaman dalam memaknai suatu fakta yang diungkapkan oleh peserta didik dalam memahami suatu konsep sehingga menyebabkan sebuah kesalahan pemahaman yang dapat menimbulkan suatu konflik di dalam pemikiran peserta didik yang dapat membuat konsep menjadi tidak benar atau bisa dikatakan sebagai kecelakaan dalam berfikir.

Banyak penelitian mengungkapkan bahwa miskonsepsi yang dialami oleh peserta didik disebabkan karena konsep yang disimpan dalam memory mereka tidak sesuai dengan tinjauan ilmiah. Miskonsepsi tersebut harus segera dihilangkan dari peserta didik, karena akan berdampak pada peserta didik itu sendiri. Miskonsepsi dapat mengganggu cara berfikir bahkan dapat melekat kuat sehingga konsep yang diterima berikutnya akan ikut melakukan kesalahan karena konsepsi awal yang salah (Siswaningsih et al., 2014).

Beberapa cara dilakukan oleh peneliti untuk mendeteksi miskonsepsi yang di alami 
oleh peserta didik. Salah satu diagnostik yang cukup akurat adalah menggunakan three-tier diagnostic text. Pada metode ini, akan disajikan sebuah soal yang disertai pilihan alasan dengan keyakinan jawaban. Peserta didik akan dihadapkan dengan sebuah alasan jawaban setelah menjawab soal. Mereka harus memilih alasan yang paling benar untuk jawaban soal. Peserta didik juga harus meyakinkan dirinya apakah jawaban yang mereka pilih adalah benar (Erlina et al., 2015).

Terintegrasinya konsep-konsep baru ke dalam pemikiran peserta didik menggantikan konsep awal yang dimiliki biasa disebut conceptual change. Untuk merubah konsep awal peserta didik, dibutuhkan perlakuan khusus dan usaha yang cukup besar. Perubahan konsep yang akan diperbaiki dapat terjadi hanya jika peserta didik mau menerima dan mempelajari kembali ketidakpahaman atau kesalahan mereka (Utami et al., 2017).

Terdapat 4 tahapan yang harus dilalui dalam conceptual change. Pertama, dengan three-tier diagnostic test yaitu ditujukan untuk menunjukkan konsepsi yang dimiliki oleh peserta didik. Tahap kedua yaitu melakukan konflik kognitif , tahap ini memberikan suatu fenomena-fenoma atau pernyataan berfikir untuk membingungkan peserta didik apakah konsep awal yang ia miliki sama dengan konsep yang sudah dikemukakan oleh para ahli. Tahap ketiga, melakukan equilibrasi. Tahap ini merupakan tahap mereview kembali materi yang telah didapatkan oleh peserta didik. Pada tahap yang terakhir melakukan rekontruksi, yang mana peserta didik mereview kembali tentang konsep yang sudah mereka ubah dalam tahap-tahap sebelumnya (Sendur \& Toprak, 2013).

Pada era perkembangan teknologi, dapat membantu meningkatkan minat dalam pembelajaran interaktif yang membuat hal-hal berbentuk abstrak dapat divisualisasikan ke dalam sebuah gambar atau media. Sistem yang berbasis teknologi cenderung tidak membosankan, karena dapat melibatkan, teks, gambar, suara hingga video.

Multimedia sangatlah penting untuk perkembangan di era sekarang. Multimedia membantu dalam berbagai banyak termasuk untuk pembelajaran. Alat-alat yang semakin canggih diharapkan dapat memudahkan dan membuat peserta didik lebih tertarik untuk belajar. Contoh Multimedia interaktif adalah: multimedia pembelajaran interaktif (pembelajaran berbasis multimedia interaktif), aplikasi game dan lain-lain (Kurniawati \& Nita, 2018).

Salah satu materi kimia yang utama dan mendasar adalah hidrokarbon. Hidrokarbon diajarkan pertama kali dalam materi kimia kelas XI. Hidrokarbon termasuk ke dalam bidang organik. Setiap kehidupan yang berhubungan dengan makhluk hidup bahkan mikroorganisme sangat bergantung pada sistem organik. Banyak pula bidang studi yang menggunakan sistem organik, seperti kedokteran dan pertanian. Penjelasan di atas memberikan pengertian bahwa miskonsepsi dalam bidang hidrokarbon harus dihindari.

Pada penelitian ini, peneliti tertarik untuk mengembangkan media interaktif untuk mendeteksi dan mereduksi miskonsepsi peserta didik sehingga lebih menarik minat belajar. Berdasarkan penelitian yang ada, penliti juga akan menggabungkan dengan three-tier diagnostic test dan conceptual change text yang diharapkan dapat memberikan dampak yang cukup besar dalam mengurangi miskonsepsi peserta didik khususnya dalam materi hidrokarbon.

\section{METODE}

Jenis penelitian yang dilakukan adalah pengembangan media interaktif pada materi hidrokarbon. Penelitian ini menggunakan metode penelitian R\&D (Research and Development). Terdapat 10 langkah pengembangan dalam metode ini, yaitu (1) potensi dan masalah, (2) pengumpulan data, (3) desain produk, (4) validasi produk, (5) revisi produk, (6) uji coba produk, (7) validasi produk, (8) uji coba pemakaian, (9) revisi produk dan (10) produksi massal (Sugiyono, 2017). Penelitian ini, yang akan dikembangkan dalam media untuk mengetahui validitas, kepraktisan dan keefektifan dari media interaktif, maka metode R\&D yang digunakan hanya sampai uji coba produk saja.

Uji coba produk dilaksanakan pada hari Selasa, tanggal 12 Januari 2020 bertempat di SMA Muhammadiyah Ponorogo pada kelas XI IPA. 


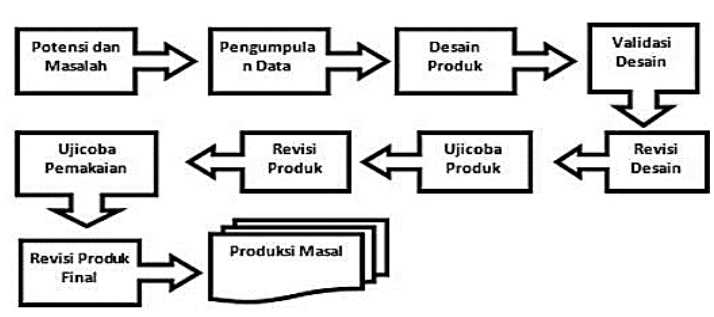

Gambar 1. Diagram Alur Rancangan Penelitian R\&D (Sugiyono, 2017)

Teknik pengumpulan data dilakukan dengan beberapa cara. Pertama adalah telaah, Hasil kegiatan telaah berupa saran dan komentar penelaah terhadap media interaktif yang telah dikembangkan oleh peneliti yang dapat digunakan untuk memperbaiki media interaktif agar layak untuk divalidasi. Data lembar telaah media interaktif dianalisis secara deskriptif kualitatif untuk memberikan gambaran dari komentar dan saran yang telah diberikan oleh dosen kimia Unesa, sehingga dapat diketahui kelemahan - kelamahan yang terdapat di dalam media interaktif yang dikembangkan dalam mengurangi miskonsepsi

Kedua, tahap validasi dilakukan untuk mengetahui kevalidan dari media interaktif sebelum diujicobakan. Validasi dibagi menjadi dua, yaitu validitas isi dan validitas konstruk. Validitas isi maupun validitas konstruk media interaktif menggunakan skala likert.

\begin{tabular}{ccc}
\multicolumn{3}{c}{ Tabel 1. Skala Likert } \\
\hline No & Penilaian & Nilai Skala \\
\hline 1 & Tidak Baik & 1 \\
2 & Kurang Baik & 2 \\
3 & Cukup & 3 \\
4 & Baik & 4 \\
5 & Sangat Baik & 5
\end{tabular}

(Riduwan, 2015).

Untuk menentukan presentase dari validitas isi dan validitas konstruk dapat menggunakan rumus :

$$
P \%=\frac{\text { Jumlah Skor }}{\text { Skor Kriteria }} \times 100 \%
$$

Untuk mengetahui hasil validasi media HACE, hasil dari presentase dapat dilihat dalam tabel skor skala likert.

Tabel 2. Interpretasi Skor Skala Likert

\begin{tabular}{ccc}
\hline No & Penilaian & $\begin{array}{c}\text { Kriteria Interpretasi } \\
\text { Skor }\end{array}$ \\
\hline 1 & $0 \%-20 \%$ & Tidak Valid
\end{tabular}

\begin{tabular}{ccc}
\hline 2 & $21 \%-40 \%$ & Kurang Valid \\
3 & $41 \%-60 \%$ & Cukup Valid \\
4 & $61 \%-80 \%$ & Valid \\
5 & $81 \%-$ & Sangat Valid \\
& $100 \%$ &
\end{tabular}

(Riduwan, 2015).

Media HACE dapat dikatakan valid apabila hasil presentase yang didapatkan mencapai $\geq 61 \%$.

Ketiga, lembar angket diberikan kepada peserta didik secara individu untuk memberikan tanggapan terhadap media interaktif sebagai hasil respon peserta didik setelah melakukan uji coba.

Analisis hasil respon peserta didik digunakan untuk mengetahui kepraktisan dari media interaktif yang dikembangkan. Analisis hasil respon yang digunakan menggunakan skala Guttman, yaitu skala Ya untuk skor 1 dan skala Tidak untuk skor 0. Presentase yang dihasilkan dapat dihitung menggunakan rumus:

$$
\begin{aligned}
& P=\frac{\text { Sjawaban Ya dari peserta didik }}{\text { Jumlah peserta didik }} \times 100 \% \\
& \text { Data yang didapatkan akan } \\
& \text { diinterpretasikan ke dalam skor skala Likert } \\
& \text { yang terdapat pada tabel di bawah ini : }
\end{aligned}
$$

Tabel 3. Interpretasi Skor Skala Likert

\begin{tabular}{ccc}
\hline No & Penilaian & $\begin{array}{c}\text { Kriteria Interpretasi } \\
\text { Skor }\end{array}$ \\
\hline 1 & $0 \%-20 \%$ & Tidak Praktis \\
2 & $21 \%-40 \%$ & Kurang Praktis \\
3 & $41 \%-60 \%$ & Cukup Praktis \\
4 & $61 \%-80 \%$ & Praktis \\
5 & $81 \%-100 \%$ & Sangat Praktis
\end{tabular}

(Riduwan, 2015).

Media HACE dapat dikatakan praktis apabila hasil presentase yang didapatkan mencapai $\geq 61 \%$.

Keempat, lembar observasi aktivitas peserta didik. Pengamatan dilakukan untuk mengamati masing-masing peserta didik pada saat aktivitas peserta didik dalam kegiatan uji coba.

Analaisis hasil observasi aktivitas peserta didik dipergunakan untuk mendukung data hasil respon peserta didik. Analisis ini menggunakan skala Guttman, dengan skala Ya untuk skor 1 dan skala Tidak untuk skor 0 . 
Presentase data hasil observasi aktivitas peserta didik dapat dihitung dengan menggunakan rumus:

$$
\begin{gathered}
P \%=\frac{\text { Jumlah peserta didik yang melakukan aktivitas }}{\text { Jumlah seluruh peserta didik }} \times 100 \% \\
\text { Data yang didapatkan akan }
\end{gathered}
$$
diinterpretasikan ke dalam skor skala likert yang terdapat pada tabel di bawah ini :

Tabel 4. Interpretasi Skor Skala Likert

\begin{tabular}{ccc}
\hline No & Penilaian & $\begin{array}{c}\text { Kriteria Interpretasi } \\
\text { Skor }\end{array}$ \\
\hline 1 & $0 \%-20 \%$ & Tidak Praktis \\
2 & $21 \%-40 \%$ & Kurang Praktis \\
3 & $41 \%-60 \%$ & Cukup Praktis \\
4 & $61 \%-80 \%$ & Praktis \\
5 & $81 \%-100 \%$ & Sangat Praktis
\end{tabular}

(Riduwan, 2015).

Media HACE dapat dikatakan praktis apabila hasil presentase yang didapatkan mencapai $\geq 61 \%$.

Terakhir, soal pretest dan posttest digunakan sebagai data untuk mengetahui keefektifan media interaktif HACE dalam mengurangi miskonsepsi yang terdapat pada peserta didik.

Teknik analisis data yang digunakan sebagai hasil merupakan sebuah pergeseran miskonsepsi. Pola jawaban yang dapat disajikan untuk mendapatkan hasil pergeseran miskonsepsi dengan three-tier diagnostic test adalah sebagai berikut.

\begin{tabular}{|c|c|c|c|}
\hline \multicolumn{4}{|c|}{ Diganostic Test } \\
\hline $\begin{array}{c}\text { First } \\
\text { Tier }\end{array}$ & $\begin{array}{l}\text { Secon } \\
\text { d Tier }\end{array}$ & $\begin{array}{l}\text { Three } \\
\text { Tier }\end{array}$ & Kategori \\
\hline Benar & Benar & Yakin & $\begin{array}{c}\text { Tahu Konsep } \\
\text { (TK) }\end{array}$ \\
\hline Benar & Salah & Yakin & $\begin{array}{c}\text { Miskonsepsi } 1 \\
(\text { MK 1) }\end{array}$ \\
\hline Salah & Benar & Yakin & $\begin{array}{c}\text { Miskonsepsi } 2 \\
\text { (MK 2) }\end{array}$ \\
\hline Salah & Salah & Yakin & $\begin{array}{l}\text { Miskonsepsi } \\
\text { (MK) }\end{array}$ \\
\hline Benar & Benar & $\begin{array}{l}\text { Tidak } \\
\text { Yakin }\end{array}$ & $\begin{array}{c}\text { Tidak Tahu } \\
\text { Konsep (TTK) }\end{array}$ \\
\hline Benar & Salahh & $\begin{array}{l}\text { Tidak } \\
\text { Yakin }\end{array}$ & $\begin{array}{c}\text { Tidak Tahu } \\
\text { Konsep (TTK) }\end{array}$ \\
\hline Salah & Benar & $\begin{array}{l}\text { Tidak } \\
\text { Yakin }\end{array}$ & $\begin{array}{c}\text { Tidak Tahu } \\
\text { Konsep (TTK) }\end{array}$ \\
\hline
\end{tabular}

Tabel 5. Pola Jawaban pada Three-Tier

$\begin{array}{cccc}\text { Salah } & \text { Salah } & \text { Tidak } & \text { Tidak Tahu } \\ & & \text { Yakin } & \text { Konsep (TTK) }\end{array}$

(Arikunto, 2012)

Pemahaman konsep peserta didik yang telah didapatkan diolah untuk didapatkan hasilnya. Peserta didik dapat dikatakan mengalami pergeseran miskonsepsi apabila mengalami pergeseran konsepsi. Semula, mengalami miskonsepsi (MK) menjadi tahu konsep (TK). Presentase pergeseran miskonsepsi dapat dihitung dengan rumus :

$$
P \%=\frac{\sum M K k e T K}{\sum M K} \times 100 \%
$$

Keterangan :

$$
\begin{array}{lll}
P \% & =\begin{array}{l}
\text { Persentase pergeseran } \\
\text { miskonsepsi dari MK } \\
\text { menjadi TK }
\end{array} \\
\sum M K \text { ke TK }= & \begin{array}{l}
\text { Jumlah peserta didik yang } \\
\text { mengalami pergeseran } \\
\text { miskonsepsi dari MK ke }
\end{array} \\
& =\begin{array}{l}
\text { TK } \\
\text { Jumlah peserta didik yang } \\
\text { mengalami miskonsepsi } \\
\text { dalam pretest }
\end{array}
\end{array}
$$

Data presentase yang diperoleh akan diaplikasikan dalam skala Likert.

Tabel 6. Interpretasi Skor Skala Likert

\begin{tabular}{ccc}
\hline No & Presemtase & Second Tier \\
\hline 1 & $0 \%-20 \%$ & Tidak Efektif \\
2 & $21 \%-40 \%$ & Kurang Efektif \\
3 & $41 \%-60 \%$ & Cukup Efektif \\
4 & $61 \%-80 \%$ & Efektif \\
5 & $81 \%-100 \%$ & Sangat Efektif
\end{tabular}

(Riduwan, 2015).

Media yang dikembangkan dapat dinyatakan efektif dan mampu mengurangi miskonsepsi terhadap peserta didik apabila terjadi pergeseran miskonsepsi dengan presentase $\geq 61 \%$.

\section{HASIL DAN PEMBAHASAN}

Hasil penelitian ini dikembangkan untuk mengetahui seberapa efektif media yang telah dibuat yang dikombinasikan dengan three-tier diagnostic test dan conceptual change text dengan acuan presentase pergeseran konsepsi peserta didik. 
Berdasarkan penelitian di suatu SMA di kota Bandung menunjukkan bahwa presentase lebih dari $75 \%$ adalah pada konsep kekhasan atom karbon, ikatan antar atom dalam rantai karbon, rantai tertutup, dan hidrokarbon tak jenuh (Siswaningsih et al., 2014). Penelitian di SMAN 4 Malang menunjukkan adanya miskonsepsi pada materi hidrokarbon, yaitu pada konsep senyawa hidrokarbon $(22,1 \%)$, konsep kekhasan atom karbon $(23,6 \%)$, konsep jenis atom karbon $(22,9 \%)$, konsep struktur dan tata nama senyawa hidrokarbon $(24,8 \%)$, konsep sifat fisik dan sifat kimia senyawa hidrokarbon $(38,7 \%)$, konsep isomer $(45,1 \%)$, dan konsep reaksi senyawa hidrokarbon $(31,4 \%)$ (Qodriyah et al., 2020). Pada penelitian di SMAN 8 Banda Aceh, diperoleh rata-rata siswa yang paham konsep terhadap materi hidrokarbon adalah $30,1 \%$, rata-rata siswa yang miskonsepsi terhadap materi hidrokarbon sebesar $16 \%$ dan yang error sebesar 6,6\%, jumlah ini lebih sedikit dari jumlah rata-rata siswa yang tidak paham konsep sebesar 47,3\%. Secara keseluruhan dapat dinyatakan bahwa siswa belum memahami materi hidrokarbon dengan benar sebesar $69,9 \%$ (Vellayati et al., 2020).

Berdasarkan penelitian tersebut, dapat dipastikan bahwa materi hidrokarbon cukup rawan terjadi miskonsepsi, materi ini juga tergolong dasar dari materi kimia. Oleh karena itu, pengembangan media yang dilakukan oleh peneliti dikhususkan untuk mata pelajaran kimia pada materi hidrokarbon yang telah dibagi menjadi 3 subkonsep, yaitu pengertian hidrokarbon dan kekhasan atom karbon; tata nama alkana, alkena dan alkuna; dan struktur atom karbon. Peserta didik akan menjawab soal pretest untuk mengetahui pemahaman konsep peserta didik, setelah itu digunakanlah conceptual change text untuk upaya merubah miskonsepsi peserta didik, dan yang terakhir diadakan postest untuk mengetahui pergeseran konsepsi yang dialami peserta didik.

Media ini ditujukan untuk peserta didik yang mengalami miskonsepsi, bukan untuk yang tidak paham konsep ataupun yang telah memahami konsep.

\section{Design Produk}

HACE dibuat menggunakan aplikasi Adobe Player Flash CS6 Action Script 3. Pada media ini terdapat beberapa bagian yang akan disajikan. Halaman pertama akan muncul sampul dengan judul dan tombol masuk, kemudian peserta didik akan mengisi identitas mereka yaitu nama, nomor absen dan asal sekolah.

Setelah mengisi identitas, peserta didik kemudian disajikan tiga soal pretest pada masing-masing sub konsep untuk mengethaui konsepsi apa yang akan mereka dapatkan. Pretest menggunakan soal three-tier diagnostic test, yaitu soal dengan tiga tingkatan (1) Soal hidrokarbon, (2) alasan jawaban, dan (3) keyakinan jawaban. Jika peserta didik mengalami miskonsepsi, maka akan diarahkan ke halaman pereduksi miskonsepsi yaitu conceptual change text., Peserta didik akan lanjut ke sub konsep selanjutnya apabila hasil yang didapatkan adalah paham konsep.

Conceptual change text terdiri atas beberapa bagian pula. Peserta didik akan dihadapkan pertanyaan apakah mereka yakin atau tidak tentang konsep yang mereka dapatkan. Kemudian akan disajikan pernyataan-pernyataan yang dapat meyakinkan seberapa ragu mereka selama ini. Setelah itu, terdapat materi-materi tentang materi hidrokarbon di dalam masingmasing sub konsep. Terakhir, peserta didik akan dihadapkan pertanyaan-pertanyaan untuk mereview kembali materi yang sudah mereka pelajari.

Setelah selesai dengan conceptual change text, akan diarahkan ke soal posttest untuk mengetahui pergeseran miskonsepsi mereka.

Berikut adalah gambaran design dari media HACE :

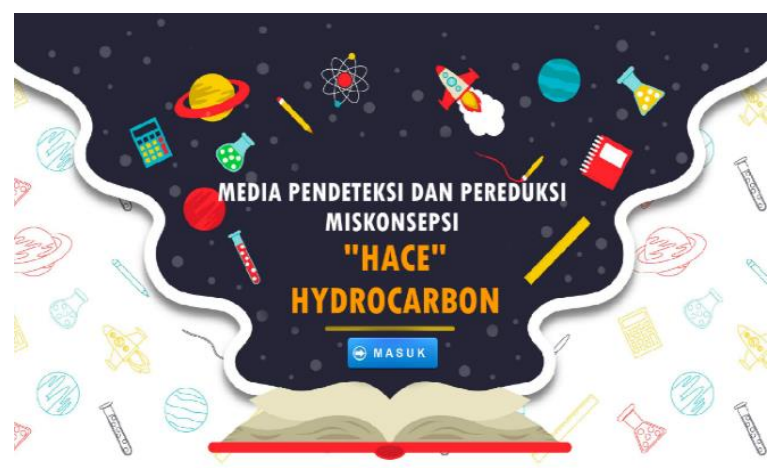

Gambar 2. Sampul depan pada media HACE

Analisis Miskonsepsi Peserta Didik dengan Three-Tier Diagnostic Test

Bentuk pretest dan posttest yang digunakan yaitu three-tier diagnostic test. 
Dalam satu soal, diagnostik ini terdapat 3 bagian, bagian pertama terdiri tes pilihan ganda, bagian kedua adalah alasan yang mengacu pada bagian pertama, dan bagian ketiga menanyakan keyakinan siswa dalam menjawab soal (Saat et al., 2016).

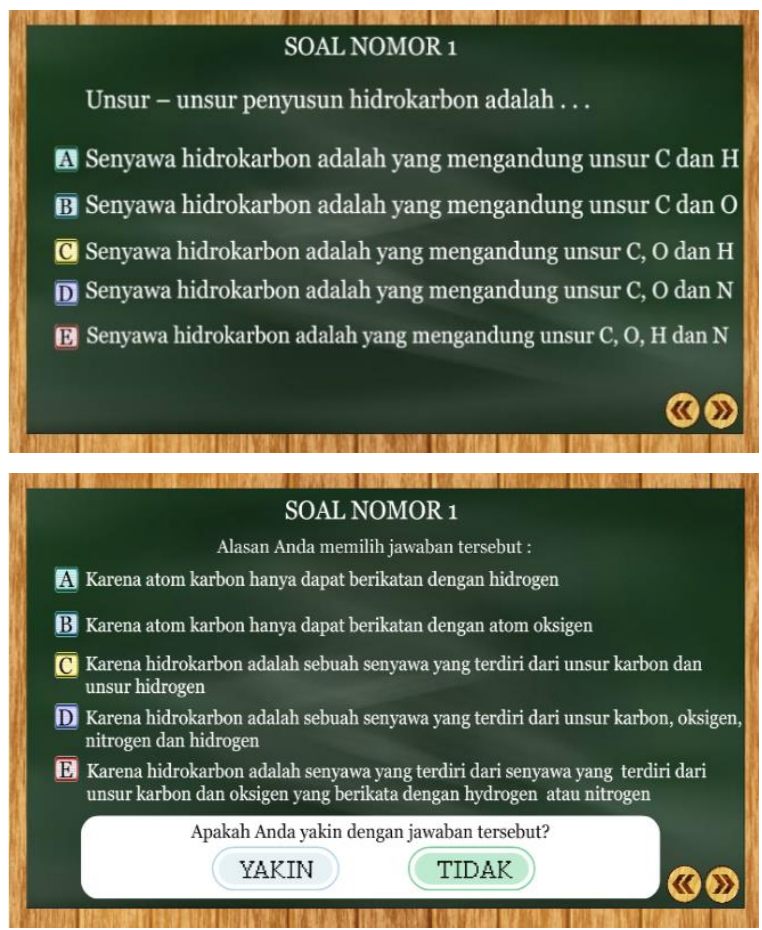

Gambar 3. Contoh soal three-tier diagnostic test pada Media HACE

Sehingga, akan memunculkan hasil pemahaman konsep awal peserta didik pada masing-masing sub konsep.

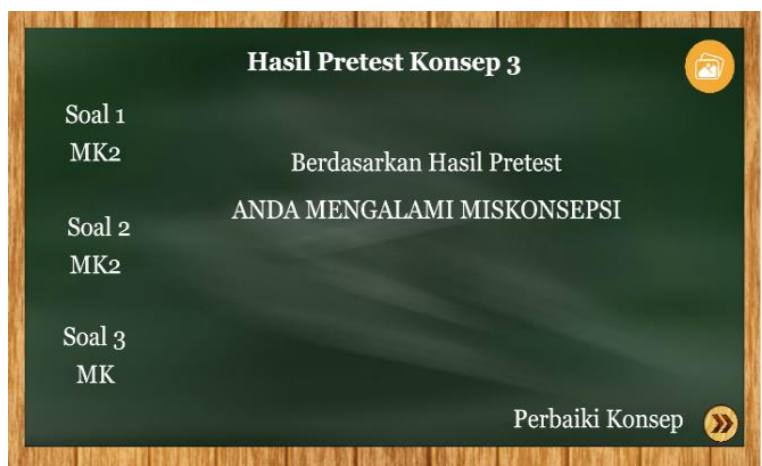

Gambar 4. Contoh hasil pemahaman konsep awal peserta didik

\section{Mereduksi Miskonsepsi Peserta Didik dengan Conceptual Change Text}

Penggunaan conceptual change text merupakan salah satu cara untuk mengurangi miskonsepsi pada peserta didik (Utami et al., 2017). Conceptual change text terdiri dari empat tahap, yaitu (1) menampilkan konsepsi siswa, (2) menciptakan konflik kognitif, (3) proses penyeimbangan (ekuilibrasi), dan (4) merekonstruksi konsep siswa (Sendur \& Toprak, 2013).

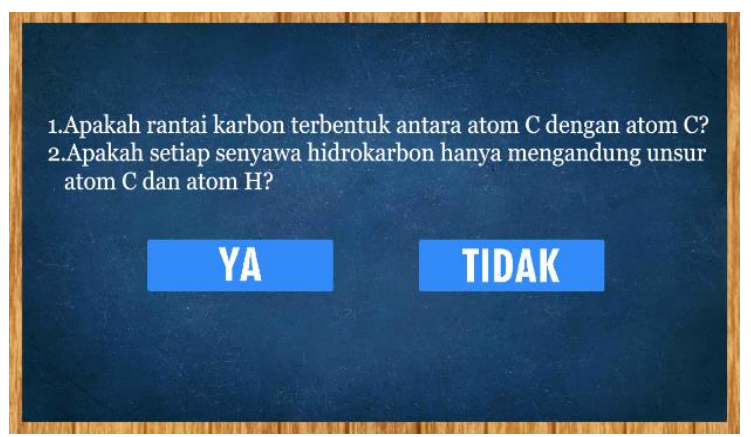

Gambar 5. Contoh tahapan konflig kognitif

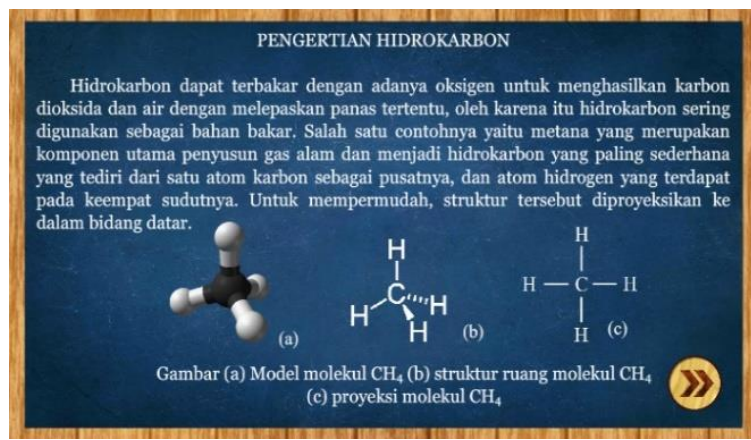

Gambar 6. Contoh tahapan equilibrasi

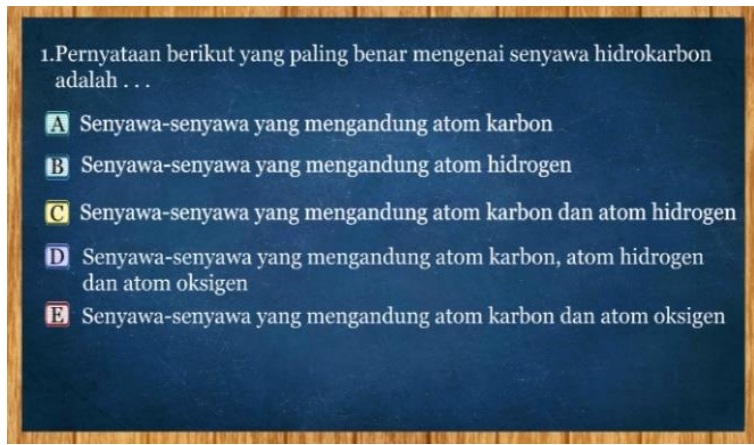

Gambar 7. Contoh tahapan rekontruksi

\section{Hasil Pergeseran Miskonsepsi Peserta Didik}

Setelah melalui conceptual change text, peserta didik dapat mengetahui pergeseran miskonsepsi yang mereka miliki. 


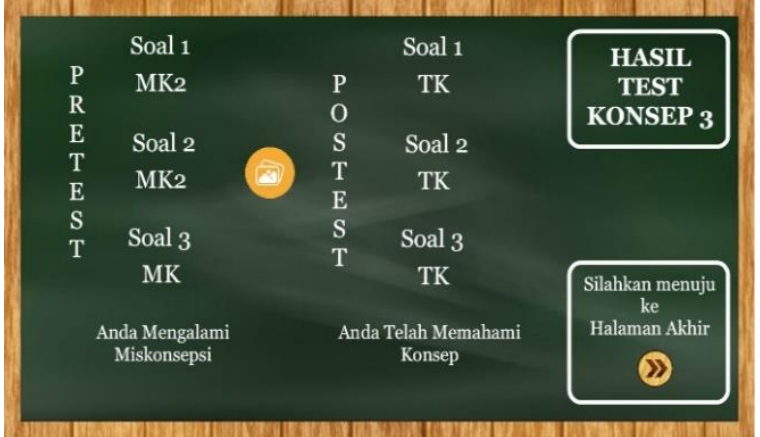

Gambar 8. Contoh hasil pergeseran konsepsi

Dari hasil pergeseran konsepsi peserta didik, data yang diperoleh dapat digunakan untuk mengetahui efektivitas dari media HACE.

\section{Hasil Validasi Design}

Validasi dilakukan oleh tiga dosen dari kimia Unesa yang dapat diketahui dari lembar telaah dan lembar validasi. Lembar validasi ada 2 jenis, yaitu validasi isi dan validasi konstruk. Hasil rata-rata validasi konstruk yang didapatkan oleh 3 validator adalah $83,42 \%$ yang berarti sangat valid, dan hasil rata-rata dari validasi isi adalah $82,45 \%$ yang berarti sangat valid. Rincian hasil validasi isi dan validasi konstruk dapat digambarkan dalam grafik berikut.

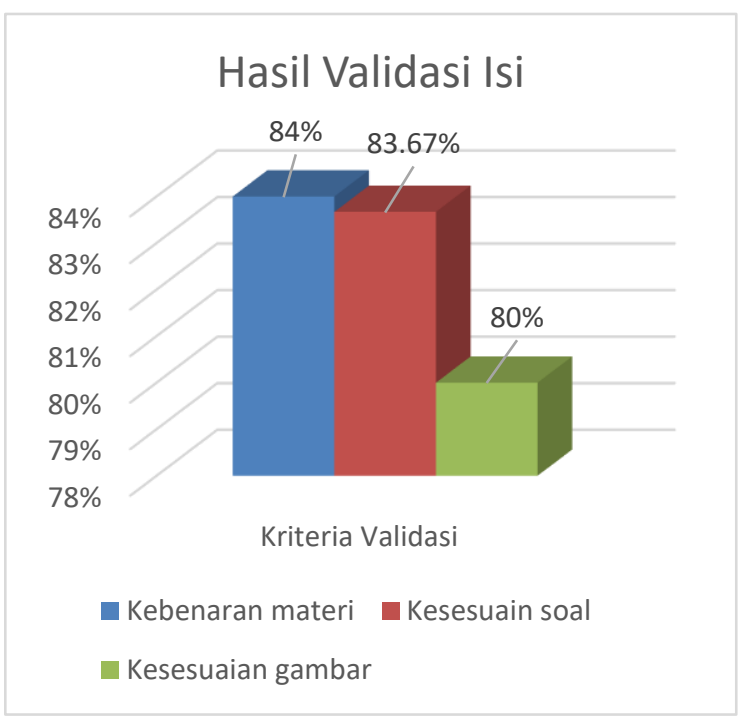

Gambar 9. Grafik validasi isi

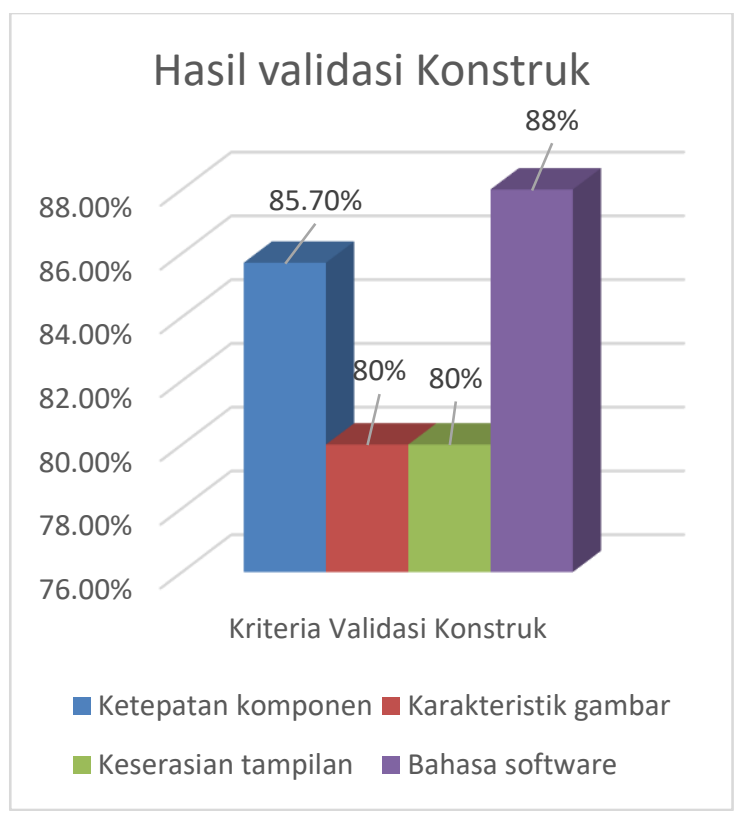

Gambar 10. Grafik validasi konstruk

\section{Revisi Design}

Revisi design digunakan untuk menyempurnakan media yang telah dibuat. Revisi dilakukan berdasarkan validasi yang telah dilakukan, komentar-komentar dari validator akan dimasukkan ke dalam media dalam segi text, gambar, maupun animasi dalam software.

Revisi media HACE terdapat pada penyederhanaan bahasa, pemanfaatan animasi pada software Adobe Flash Player CS6 dan keserasian isi materi.

\section{Uji Coba Produk}

Pada uji coba produk, media HACE diujicobakan kepada 7 peserta didik kelas XI SMA Muhammadiyah Ponorogo yang telah menerima materi hidrokarbon. Pada tahap ini dilakukan dengan tujuan untuk mengetahui efektivitas dari media HACE.

\section{Efektivitas Media HACE}

Aspek efektivitas media HACE ditinjau berdasarkan hasil dari pergeseran konsepsi peserta didik. Berdasarkan data yang diperoleh dari penggunaan media, terdapat perubahan pergeseran konsepsi yang cukup signifikan dari masing-masing peserta didik yang diujicobakan. Dapat dilihat pada tabel berikut.

Tabel 7. Pergeseran sub konsep pengertian 
hidrokarbon dan kekhasan atom karbon

\begin{tabular}{|c|c|c|c|c|}
\hline No & Nama & Soal & Pretest & Postest \\
\hline \multirow[t]{3}{*}{1} & $\mathrm{ABK}$ & Soal 1 & TK & TK \\
\hline & & Soal 2 & $\mathrm{TK}$ & TK \\
\hline & & Soal 3 & MK & TK \\
\hline \multirow[t]{3}{*}{2} & CAP & Soal 1 & MK1 & TK \\
\hline & & Soal 2 & MK & TK \\
\hline & & Soal 3 & MK & TK \\
\hline \multirow[t]{3}{*}{3} & FA & Soal 1 & TK & TK \\
\hline & & Soal 2 & MK1 & TK \\
\hline & & Soal 3 & MK & TK \\
\hline \multirow[t]{3}{*}{4} & KA & Soal 1 & TK & TK \\
\hline & & Soal 2 & MK1 & TK \\
\hline & & Soal 3 & TK & TK \\
\hline \multirow[t]{3}{*}{5} & NAYP & Soal 1 & TK & TK \\
\hline & & Soal 2 & MK & TK \\
\hline & & Soal 3 & MK & TK \\
\hline \multirow[t]{3}{*}{6} & RAP & Soal 1 & TK & TK \\
\hline & & Soal 2 & MK & TK \\
\hline & & Soal 3 & MK & TK \\
\hline \multirow[t]{3}{*}{7} & RADA & Soal 1 & MK & TK \\
\hline & & Soal 2 & TK & TK \\
\hline & & Soal 3 & MK & TK \\
\hline
\end{tabular}

Pada sub konsep pengertian hidrokarbon dan kekhasan atom karbon, peserta didik yang mengalami miskonsepsi dikarenakan peserta didik beranggapan bahwa hidrokarbon merupakan senyawa yang mengandung unsur $\mathrm{C}$, $\mathrm{H}$ dan $\mathrm{O}$. konsep yang benar adalah senyawa hidrokarbon hanya terdiri dari unsur $\mathrm{C}$ dan $\mathrm{H}$, jika terdapat unsur lain seperti $\mathrm{O}$ berada didalam senyawa tersebut maka termasuk dalam senyawa karbon (Badri, 2018). Pada konsep kekhasan atom karbon juga banyak terdapat miskonsepsi, hal ini dikarenakan banyak yang tidak paham mengenai penentuan golongan dan periode dari atom karbon. Golongan dan periode dari sebuah unsur dapat dilihat dari konfigurasi elektronnya. Golongan suatu unsur ditunjukkan dari elektron kulit terluar (valensi) dan periode dapat ditentukan dari jumlah kulit yang telah terisi elektron (Yeni et al., 2010). Sehingga setelah mengalami tahapan mereduksi miskonsepsi, terjadi perubahan yang sangat signifikan, semua peserta didik dapat mengalami perubahan konsep dari miskonsepsi menjadi tahu konsep.

Tabel 8. Pergeseran sub konsep tata nama alkana, alkena dan alkuna

\begin{tabular}{ccccc}
\hline No & Nama & Soal & Pretest & Postest \\
\hline 1 & ABK & Soal 1 & MK & MK1 \\
& & Soal 2 & MK2 & TK \\
& & Soal 3 & MK & TK \\
2 & CAP & Soal 1 & MK1 & TK
\end{tabular}

\begin{tabular}{|c|c|c|c|c|}
\hline & & Soal 2 & MK2 & TK \\
\hline & & Soal 3 & MK1 & TK \\
\hline 3 & FA & Soal 1 & MK & TK \\
\hline & & Soal 2 & TK & TK \\
\hline & & Soal 3 & MK & TK \\
\hline 4 & KA & Soal 1 & MK1 & TK \\
\hline & & Soal 2 & MK & TK \\
\hline & & Soal 3 & MK & MK2 \\
\hline 5 & NAYP & Soal 1 & MK & TK \\
\hline & & Soal 2 & MK & TK \\
\hline & & Soal 3 & MK & TK \\
\hline 6 & RAP & Soal 1 & MK1 & TK \\
\hline & & Soal 2 & MK & TK \\
\hline & & Soal 3 & MK & TK \\
\hline 7 & RADA & Soal 1 & TK & TK \\
\hline & & Soal 2 & MK & TK \\
\hline & & Soal 3 & MK & TK \\
\hline
\end{tabular}
alkena dan alkuna, masih terdapat 2 peserta didik yang masih mengalami miskonsepsi selebihnya sudah mengalami pergeseran konsepsi menjadi tahu konsep. Secara teori, peserta didik tahu cara menentukan langkah-langkah untuk menamai suatu senyawa hidrokarbon. Banyak peserta didik yang terkecoh dengan rantai terpanjang, mereka menentukan rantai terpenjangan sama dengan rantai yang lurus. Padahal struktur tersebut masih memiliki rantai terpanjang yang lain (Rahmawati et al., 2018).

Tabel 9. Pergeseran sub konsep struktur atom karbon

\begin{tabular}{|c|c|c|c|c|}
\hline \multicolumn{5}{|c|}{ Rat } \\
\hline No & Nama & Soal & Pretest & Postest \\
\hline \multirow[t]{3}{*}{1} & ABK & Soal 1 & MK & TK \\
\hline & & Soal 2 & MK & TK \\
\hline & & Soal 3 & MK1 & TK \\
\hline \multirow[t]{3}{*}{2} & CAP & Soal 1 & MK & TK \\
\hline & & Soal 2 & MK2 & TK \\
\hline & & Soal 3 & MK & TK \\
\hline \multirow[t]{3}{*}{3} & FA & Soal 1 & MK & TK \\
\hline & & Soal 2 & MK & TK \\
\hline & & Soal 3 & TK & TK \\
\hline \multirow[t]{3}{*}{4} & KA & Soal 1 & MK & TK \\
\hline & & Soal 2 & MK & MK1 \\
\hline & & Soal 3 & MK & MK2 \\
\hline \multirow[t]{3}{*}{5} & NAYP & Soal 1 & MK2 & TK \\
\hline & & Soal 2 & MK2 & TK \\
\hline & & Soal 3 & MK & $\mathrm{TK}$ \\
\hline \multirow[t]{3}{*}{6} & RAP & Soal 1 & TK & TK \\
\hline & & Soal 2 & MK2 & TK \\
\hline & & Soal 3 & MK & TK \\
\hline \multirow[t]{3}{*}{7} & RADA & Soal 1 & TK & TK \\
\hline & & Soal 2 & MK2 & TK \\
\hline & & Soal 3 & MK2 & TK \\
\hline
\end{tabular}


Pada sub konsep struktur atom karbon, masih terdapat 1 peserta didik yang tidak mengalami pergeseran konsepsi dari miskonsepsi menjadi tahu konsep. Miskonsepsi terjadi karena peserta didik masih belum memahami atom karbon primer, sekunder, tersier dan kuartener. Kebanyakan dari peserta didik mengelompokkan atom karbon berdasarkan kemampuan atom $\mathrm{C}$ dalam mengikat atom $\mathrm{H}$, bukan kemampuan atom $\mathrm{C}$ dalam mengikat atom karbon yang lain. Peserta didik mengalami kesalahan dalam menjawab soal dikarenakan kurangnya ketelitian dalam melihat struktur senyawa, tidak bisa memahami soal dengan baik sehingga salah dalam menentukan jumlah atom primer (Nuryana \& Rosyana, 2019).

Data yang diperoleh akan diolah atau dihitung menggunakan rumus

$$
P \%=\frac{\sum M K k e T K}{\sum M K} \times 100 \%
$$

Dari 7 peserta didik, terdapat 5 yang berhasil mengubah konsepsi menjadi tahu konsep, dan 2 masih belum berhasil mengubah menjadi tahu konsep. Media yang dikembangkan dapat dinyatakan efektif dan mampu mereduksi miskonsepsi apabila skor presentasi mencapai $\geq 61 \%$ (Riduwan,2015). Menurut perhitungan yang didapatkan dari rumus, keefektifan media HACE memperoleh presentase sebesar $71,42 \%$. Media tergolong sebagai kriteri yang efektif, dapat dilihat pada tabel 7 yang menunjukkan interpretasi skor skala Likert.

\section{PENUTUP}

Berdasarkan hasil penelitian yang telah dikemukakan di atas, dapat disimpulkan bahwa media HACE dikombinasikan dengan three-tier diagnostic test dan conceptual change mengalami penelitian yang bisa dikatakan cukup lancar,

Hasil rata-rata yang didapatkan dari validasi konstruk yang didapatkan oleh 3 validator adalah $83,42 \%$ yang berarti sangat valid, dan hasil rata-rata dari validasi isi adalah $82,45 \%$ yang berarti sangat valid.

Uji coba produk dilakukan kepada 7 peserta didik di kelas XI SMA Muhammadiyah Ponorogo yang telah menerima materi hidrokarbon. Pada subkonsep pengertian hidrokarbon dan kekhasan atom karbon, seluruh peserta didik berhasil mengalami pergeseran konsepsi dari miskonsepsi menjadi tahu konsep. Sedangkan, subkonsep tata nama alkana, alkena dan alkuna masih terdapat 2 peserta didik yang belum mengalami pergeseran miskonsepsi. Sub konsep struktor atom karbon juga masih terdapat peserta didik yang belum mengalami pergeseran miskonsepsi sebanyak 1 peserta didik.

Hasil akhir penelitian ini didapatkan presentase pergeseran miskonsepsi sebesar $71,42 \%$. Hal ini berarti menunjukkan bahwa media HACE dapat dikatakan efektif atau mampu mengurangi miskonsepsi, karena sesuai dengan interpretasi skor skala likert yang menyatakan jika media yang dikembangkan dapat dinyatakan efektif dan mampu mengurangi miskonsepsi terhadap peserta didik apabila terjadi pergeseran miskonsepsi dengan presentase $\geq 61 \%$.

\section{DAFTAR PUSTAKA}

Arikunto, S. (2012). Prosedur Penelitian Suatu Pendekatan Praktek. Jakarta: Rineka Cipta.

Badri, S. S. I. (2018). Pengembangan Ludo Word Game Sebagai Media Pembelajaran Pada Materi Hidrokarbon Kelas XI SMA. Jurnal Penelitian Dan Kajian Ilmiah: Menara Ilmu, XII(12), 70-80.

Erlina, N., Wasis, \& Wicaksono, I. (2015). Pengembangan Dan Penerapan ThreeTier Test Untuk Mengukur Keterampilan Penalaran Ilmiah Siswa SMA. Prosiding Seminar Nasional Pendidikan Fisika 2016, 1(0711), 568-575.

Kurniawati, I. D., \& Nita, S. (2018). Media Pembelajaran Berbasis Multimedia Interaktif Untuk Meningkatkan Pemahaman Konsep Mahasiswa. Journal of Computer and Information Technology, I(2),

68.

https://doi.org/10.25273/doubleclick.v1i2 .1540

Nuryana, D., \& Rosyana, T. (2019). Analisis Kesalahan Siswa SMK dalam Menyelesaikan Soal Pemecahan Masalah Matematik pada Materi Program Linear. Jurnal Cendekia: Jurnal Pendidikan Matematika, 3(1), 11-20.

Qodriyah, N. R. L., Rokhim, D. A., Widarti, H. R., \& Habiddin. (2020). Identifikasi Miskonsepsi Siswa Kelas XI SMA Negeri 
4 Malang Pada Materi Hidrokarbon Menggunakan Instrumen Diagnostik Three Tier. Jurnal Inovasi Pendidikan Kimia, 14(2), 2645.

Rahmawati, S., Ashadi, \& Susilowati, E. (2018). Student's Profile About Critical Thinking Ability on Hydrocarbon Compounds Concept. In AIP Conference Proceedings (Vol. 2014). https://doi.org/10.1063/1.5054451

Riduwan. (2015). Dasar-Dasar Statistika. Bandung : Alfabeta.

Saat, R. M., Fadzil, H. M., Aziz, N. A. A., Haron, K., Rashid, K. A., \& Shamsuar, N. R. (2016). Development of an Online ThreeTier Diagnostic Test to Assess PreUniversity Students' Understanding of Cellular Respiration. Journal of Baltic Science Education, 15(4), 532-546.

Sendur, G., \& Toprak, M. (2013). The Role of Conceptual Change Texts to Improve Students' Understanding of Alkenes. Journal Chemistry Education Research and Practice, 14(4), 431-449. https://doi.org/10.1039/c3rp00019b

Siswaningsih, W., Hernani, H., \& Rahmawati, T. (2014). Profil Miskonsepsi Siswa Sma Pada Materi Hidrokarbon Menggunakan Tes Diagnostik Pilihan Ganda Dua Tingkat. Jurnal Penelitian Pendidikan Kimia: Kajian Hasil Penelitian Pendidikan Kimia, 1(2), 200-206. https://doi.org/10.36706/jppk.v1i2.1898

Sugiyono. (2017). Metode Penelitian Kuantitatif, Kualitatif, dan $R \& D$. Bandung : CV Alfabeta.

Utami, D. B., Rahmawati, Y., \& Slamet, R. (2017). Penggunaan Conceptual Change Text Dengan Model Pembelajaran 5E Untuk Mengatasi Miskonsepsi Siswa Pada Materi Asam Basa Di Sman 4 Tambun Selatan. JRPK: Jurnal Riset Pendidikan Kimia, 7(1), 30-37. https://doi.org/10.21009/jrpk.071.10

Vellayati, S., Nurmaliah, C., \& Saidi, N. (2020). Identifikasi Tingkat Pemahaman Konsep Siswa Menggunakan Tes Diagnostik Three-Tier Multiple Choice pada Materi Hidrokarbon. Jurnal Pendidikan Sains Indonesia (Indonesian Journal of Science Education), $\quad$ 8(1), 128-140. https://doi.org/10.24815/jpsi.v8i1.15715

Yeni, Hoendarto, G., \& Antonius. (2010). Aplikasi Hitung Konfigurasi Elektron Dalam Sistem Periodik Unsur Kimia. Jurnal Masitika (Jurnal Mahasiswa Sistem Infromasi Dan Teknik Informatika), 1-12.

Yuliati, Y. (2017). Miskonsepsi Siswa Pada Pembelajaran IPA Serta Remediasinya. Journal Bio Educatio, 2(2), 50-58. 